International Journal of Canadian Studies

Revue internationale d'études canadiennes
INTERNATIONAL JOURNAL OF CANADIAN STUDIES

REVUE INTERNATIONALE D'ÉTUDES CANADIENNES

\title{
Introduction: Uncovering Canada's Environmental Cultural Politics
}

\section{Randolph Haluza-DeLay}

Numéro 39-40, 2009

Culture - Natures in Canada

Culture - natures au Canada

URI : https://id.erudit.org/iderudit/040826ar

DOI : https://doi.org/10.7202/040826ar

Aller au sommaire du numéro

Éditeur(s)

Conseil international d'études canadiennes

ISSN

1180-3991 (imprimé)

1923-5291 (numérique)

Découvrir la revue

Citer ce document

Haluza-DeLay, R. (2009). Introduction: Uncovering Canada's Environmental

Cultural Politics. International Journal of Canadian Studies / Revue

internationale d'études canadiennes, (39-40), 131-136.

https://doi.org/10.7202/040826ar 


\section{Randolph Haluza-DeLay}

\section{Introduction: Uncovering Canada's Environmental Cultural Politics}

Political action is a product of socio-cultural processes, drawing on values, ideas, institutions, discourse and other cultural resources to create particular policy instruments that fit the social and political zeitgeist of the times. It is widely recognized that ideas of "nature" or "the environment" are dialectically produced by material and symbolic practice. Many scholars have demonstrated and unsettled the primacy of a "wilderness" trope as dominating Canadian identity. Yet greater attention needs to be devoted to the cultural dimensions of the environment and environmental politics in Canadian Studies. Such politics lie at intersections of natural and social sciences and the humanities, and in the interplay of rhetoric, practice, policy, social norms, and organizational forms.

Despite extensive recent media attention to the environment, these are dimensions rarely brought into the open. Instead, the environment is usually assumed to be a matter primarily for the natural sciences and environmental degradation expected to be ameliorated by technological solutions. Into conditions established by such assumptions, the papers of this special section demonstrate that "the environment" is a matter of cultural politics in the Canadian social landscape. By incorporating socio-cultural dimensions, a cultural politics of the environment directs environmental analysis toward effectively addressing environmental concerns. If Canadian Studies is about gaining "a better understanding of [the] country, its history, stories, people and institutions"-as the federal Department of Canadian Heritage declares - uncovering how culture and politics intersect on environmental matters is a central heuristic for discerning not only environmental politics in Canada, but also important aspects of the Canadian imaginary and social terrain.

Culture is one of the most difficult concepts in the social sciences. All arenas in which humans engage are ineluctably "cultural," including the political, economic and environmental arenas. So while culture is often used to mean behaviour, material objects and signification systems, "in practice, cultural systems contain a great deal more, coding for the knowledge, practices, beliefs, worldviews, values, norms, identities, livelihoods and social organisations of human societies' (Pretty et al. 2). Milton summarized three key features of culture in an anthropological 
conception - that it consists of perceptions and interpretations (people making sense of their experience in collective and dynamic processes); that it is expressed by what people say and do (with discursive and behavioural practices accumulating in institutional forms); and that it is the central mechanism through which we interact with our environment. That environment consists of social and biophysical factors means the human realm cannot be seen to exist "above" the biophysical as a Nature/Culture dichotomy. Human cultures are integrally located within that realm, yet behavioural and interpretive dimensions also shape the ways that the interaction occurs with the biophysical.

Thus, culture shapes responses to the environment in ways of which people may be entirely unaware. In some fashion, nature interpellates us, but culture shapes whether and how we can respond to the hailing. Cultural diversity makes this clear. The plurality of human cultures includes their diverse and sometimes contrasting models of human relations with nature and the institutions they have formed to structure these relations. Because of this, "the maintenance of cultural diversity into the future, and the knowledge, innovations and outlooks it contains increases the capacity of human systems to adapt and cope with change" (Pretty et al. 2).

Cultural politics is "an approach that treats culture itself as a site of political struggle, an analytic emphasizing power, process and practice" (Moore, Kosek \& Pandian 2). This definition goes beyond a "politics of identity" typically associated with the notion of cultural politics. From the very beginning of Canadian environmental studies, Evernden, Livingstone, and Wilson illustrated the significance of cultural elements in the ways that Canadians could perceive, comprehend and act about that which they called "the environment." And although they have not identified their work as such, Canadian scholars like Northrop Frye have long demonstrated that culture and the biophysical interact in the cultural imaginary, institutions, and politics of Canada.

Programmes for addressing environmental problems often rely on technical projects, rational planning; regulations (or lately, "voluntary compliance"), or "education." Without attention to cultural dimensions, such programmes are ineffective. They miss the values, norms, institutional forms and social practices by which people live and routinize their lives. Such programmes also miss the power relations that shape and reshape the Canadian landscape, ecosystems, pollutants, resource extraction, energy demands, ideas and lifestyles. Remedies to environmental degradation do not simply entail better knowledge, technology or systems of organization; they require cultural change.

If culture is a site of environmental politics, culture is also an element of the political struggle itself. Early 20th Century wildlife management 
regimes were specifically designed to restrict native hunting because of different cultural constructions of the landscape and hunting as sport or subsistence (Sandlos). Canadian political representations of the land clearly sought to erase the presence of existing people from it, allowing new occupations by "legitimate" settlers (Cole; Giesbrecht; Peake, Ray). Multiculturalism is a pillar of the state-sanctioned construct of Canadian identity, but it is rarely coupled with another such pillar: wilderness (Baldwin; Mackay). Values, practices and meanings held by particular social groups are unrecognized by the political culture of other actors, as in Page's study of Aboriginal participation in West Coast aquaculture planning.

Environmental policies and agreements are cultural products and active instruments in the cultural struggle. Carlson describes this in his analysis of the James Bay and Northern Québec Agreement (1975).

It brought to an end the Cree ability to define that land exclusively within their own language and assumptions about culture and nature. Since 1975 the Cree have continued to talk to one another about the earth and their place in it, but they have also been forced to explain their culture to outsiders within a legal and political framework that is not flexible enough to hold many of their cultural concepts. The land, instead of being solely the centre of a cultural cosmos, has also become a source of political and environmental debate both inside and outside Cree culture. (Carlson 64).

Environmental injustices are often functions of cultural conflict (Agyeman, Cole, Haluza-DeLay, O'Riley). Distributional inequitymaldistribution of environmental risks or amenities - is only the beginning of environmental injustice (and usually requires validation by the cultural production of empirical data production). Also salient are procedural inequities. The participatory ability of marginalized and environmentally at-risk peoples often hinges on their cultural competence in the procedural mechanisms that govern environmental decision making, their cultural capital in assimilating information and communicating their risks, and the social networks to compete with corporate actors with more resources. The pursuit of environmental justice necessitates the tools of cultural politics. But answers to deeper issues of a politics of recognition may need to be uncovered for environmental justice to be realized:

Such questions as Who has standing? On what concerns? What are the legitimation processes by which social and symbolic meaning are attributed to these questions? What constitutes power, and what are the contexts with respect to those with power and those without? (Agyeman et al 8)

Examining the cultural politics of the environment makes clear that the answers to these questions will vary according to the knowledges, norms, policies, and institutional forms that are used to answer them. As Schlosberg (9) explains further, "If differences are constituted in part by 
social, cultural, economic, and political processes, any examination of justice needs to include discussions of the structures, practices, rules, norms, language, and symbols that mediate social relations." These are among the tools of analysis in a cultural politics of the environment, and they are deployed in the six papers in this special section of this journal as the analyses lay bare the "power, processes and practices" of Canadian environmental culture and politics.

Lynne Davis opens by illuminating the stages of relations between environmental non-governmental organizations (ENGOS) and First Nations on the British Columbia coast in the past two decades. Environmental groups have had an effect on contemporary Aboriginal struggles, including both specific and comprehensive land claims, treaty rights, and resource management agreements. Thus, the tenuous coalitions among ENGOs and First Nations become cultural politics, and each stage involves learning of the other and the (re)negotiation of Aboriginal/settler power relations.

Catriona Sandilands describes a different sort of legitimation of cultural histories in her analysis of Canadian National Parks. She ties the new mandate of parks managed for "ecological integrity" to the long-standing nation-building projects for which national parks have long been used. As Sandilands explains, "ecological integrity" serves as another form of historical erasure since it depends on notions of "unbroken nature" unaffected by human occupation. Nature's "integrity" becomes a cultural product.

Doug MacDonald's study begins from acknowledgement that environmental norms are continually changing and actors are actively engaged in these cultural processes. And the federal government has done culturework in pursuit of its own "environmental legitimacy." MacDonald uses this term to mean "the belief in the eyes of the Canadian public that the values and actions of a particular actor... are proper and sufficient to guard against undue environmental harm." Legitimacy can be pursued by appropriate action, by creating an image of appropriate action, or by changing the norms by which action is deemed appropriate. The federal government has actively managed its image while working to shift the standards of judgement toward that of sustainable development and away from more dramatic politics of cultural change.

The environmental movement may have accommodated to a new culture of sustainable development from its roots in a deeper ecological critique. Lorelei Hanson and Gloria Filax describe the policy instrument of conservation land trusts which are designed to use market tools and private property for environmental conservation. As markets are a cultural form, so this policy tool is cultural politics. While land trusts deliberately serve the 
public good, they are a privatized mechanism for doing so. Thus, they are part of the struggle for culture, and Hanson and Filax ask if they are acceptable conservation tools, examples of corporate environmentalism, or policy instruments of a political culture that accommodates environmental protection to the ruling relations of the times.

Marie Vander Kloet goes even further by showing that some cultural politics of the environment may lead participants to consent with the hegemony of the economic arena. Mountain Equipment Co-op is a modern Canadian cultural icon. While putatively a member cooperative, it is the largest retailer of outdoor recreation gear in the country. "MEC" deliberately invests in culturework, "structuring how wilderness is understood by its members." From a place to buy gear to consuming wilderness and nation, to constructing the political subject as consumer and consumption as political engagement, MEC conducts a distinct cultural politics of the environment that Vander Kloet slowly and carefully uncovers.

MEC's construction of Canadian landscapes is far removed from the Blackfoot worldview narrated by Cynthia Chambers and Narcisse Blood. The story of the land includes the extirpation of the Blackfoot. The "vanishing" of the bison was no magic act, except as an act of language that vanishes colonial histories too. Chambers and Blood define the repatriation of sacred items as environmental politics. Important sites are alive in ceremonial objects; these objects (bundles) contain parts of plant, animal, and geologic life tied to specific places. "Places [as] animate beings with whom humans live in relationship" unite people and land in a way that transcends the social geographical mapping of identity to place; this unity was and continues to be damaged by the onslaught of colonialism, the enclosure of the bundles to museums, and the renaming of sacred sites as heritage "resources." Chambers and Blood conclude with hope: "Siksikáitapiiksi and Náápiikoaksi are called to love thy neighbour, to work together, to ensure kitáóowahsinnoon continues to nourish us all."1

Each of the essays in this special section unpacks, illuminates, and makes visible the often hidden forces that would cause us to think these topics immutable and universal rather than contingent and particular. Whether examining the political culture of actors, or demonstrating how environmental politics is a form of culturework, these papers uncover intersections of human action, culture, and the environment. Such uncovering of the ways these things intersect means that other patterns of intersection are also possible. We are not limited to the trajectory that has gotten us to the rather gloomy prognosis of future environmental degradation and a politics of denial to the point of ignorant inaction. These analyses are not that form of cultural politics that Giddens called "lifestyle politics." A cultural politics of the environment is a move toward 
expansively emancipatory politics, because they uncover the often invisible chains that limit effective environmental programmes. In the end, pulling back the covers of a cultural politics of the environment in Canada may provoke coupling with a reimagined environmental praxis and gestate a new politics that will effectively protect and restore environmental, vitality for all beings in the land, air, water and minds of Canada.

\section{Notes}

1. A glossary is provided for English speakers.

\section{Works Cited}

Agyeman, Julian, Peter Cole, Randolph Haluza-DeLay, and Pat O'Riley (Eds). Speaking for Ourselves: Environmental Justice in Canada. Vancouver, BC: University of British Columbia Press, 2009.

Baldwin, Andrew. "The White Geography of Lawren Stewart Harris: Whiteness and the Performative Coupling of Wilderness and Multiculturalism." Environment and Planning $A 41$ (2009): 529-44.

Carlson, Hans M. "A Watershed of Words: Litigating and Negotiating Nature in Eastern James Bay, 1971-1975. The Canadian Historical Review 85.1 (2004): 63-84.

Cole, Peter. Coyote and Raven Go Canoeing: Coming Home to the Village. Montreal: McGill-Queen's University Press, 2006.

Evernden, Neil. The Natural Alien. Toronto: University of Toronto Press, 1985.

Giesbrecht, Donovan. "Métis, Mennonites and the 'Unsettled Prairies'." Journal of Mennonite Studies 19 (2001): 103-111.

Livingston, John A. The fallacy of wildlife conservation. Toronto: McClelland \& Stewart, 1981.

Mackey, Eva. The House of Difference: Cultural Politics and National Identity in Canada. Toronto: University of Toronto Press, 2002.

Milton, Kay. Environmentalism and Cultural Theory. London: Routledge, 1996.

Moore, Donald S., Jake Kosek, and Anand Pandian (Eds). Race, Nature, and the Politics of Difference. Durham, NC: Duke University Press, 2003.

Page, Justin. "Salmon Farming in First Nations' Territories: A Case of Environmental Injustice on Canada's West Coast." Local Environment 12. 6 (2007):613-26.

Peake, Linda and Brian Ray. "Racializing the Canadian Landscape." The Canadian Geographer 45.1 (2001):93-98.

Pretty, Jules and et al. "How Do Biodiversity and Culture Intersect?" Sustaining cultural and biological diversity in a rapidly changing world: Lessons for global policy (American Museum of Natural History, Washington D.C., May 2-5, 2008; http://symposia.cbc.amnh.org/archives/biocultural/pdf-docs/intersect.doc).

Sandlos, John. Hunters at the Margin: Native People and Wildlife Conservation in the Northwest Territories. Vancouver: University of British Columbia Press, 2007.

Wilson, Alexander. The Culture of Nature. Toronto: Between the Lines, 1991. 